\title{
De/Constructing Friedrich Hölderlin: The Year in Germany
}

Der große Unbekannte, the big unknown in German literature, is how Rüdiger Safranski introduces Friedrich Hölderlin (1770-1843) in his new book on the contemporary of Johann Wolfgang von Goethe, the protégé of Friedrich Schiller, and the schoolmate of Georg Wilhelm Friedrich Hegel. On the occasion of Hölderlin's $250^{\text {th }}$ birthday, the German publishing house Hanser has put out two books on the poet's life and his legacy that couldn't be more different from each other. Yet at the same time, they both revolve around the Geheimnis, the mystery, that surrounds Hölderlin's literary work as well as his tragic fate. While Safranski's interest in that respect is mainly biographical and thus he discusses the poet's decline into madness, Karl Heinz Ott traces the dazzling afterlife of Hölderlin's enigmatic oeuvre. The title of Ott's book, Hölderlins Geister, is deliberately ambiguous, as Geist can translate to either spirit, mind or phantom. The plural form of the noun indicates that it is not just one Hölderlin that we encounter in Ott's extensive essay, but several, ranging from the herald of Greek mythology to the Jacobin revolutionary or the icon of German nationalism. In accordance, the book's five chapters are entitled Tübinger Visionen, visions of Tübingen, Der bräunliche Hölderlin, the brownish Hölderlin, alluding to the brown uniforms of the Nazi's paramilitary troops, Die Wahnsinnsmaske, the mask of madness, Griechisches Licht, Greek light, and Forever Young (in English). Hölderlin thus appears as the often only vaguely discernible center of a wider circle of spiritually akin figures like Friedrich Nietzsche, Stefan George, and most notably Martin Heidegger. From Ott's perspective, this panorama of German philosophical thought is predominantly, if not exclusively, male, which comes as a surprise, taking into account that Bettine von Arnim, one of German Romanticism's sharpest minds and arguably its most prominent female voice, was largely responsible for the fact that Hölderlin's poetic work would not be forgotten.

While Ott's critical acknowledgement spreads out and around Hölderlin and his legacy, Safranski opts for a more conventional narrative. This is in accordance with his books on E. T. A. Hoffmann, Martin Heidegger, Johann Wolfgang von Goethe and Friedrich Schiller, which have all become bestsellers and turned the author into one of Germany's most distinguished living biographers. In the first chapters, one learns about Hölderlin's childhood in Würtemmberg, in the southeast of Germany. As he lost both his biological father and stepfather quite early on, his mother become the dominant figure in his family, and she remained a central, yet problematic character until the end of the poet's life. Part of the reason is that she administrated her son's considerable inheritance, which she refused to pay out to him until he were to take up a secure 
profession, ideally the respected post of a country parson, and find a family of his own. To her great dissatisfaction, Hölderlin had very different ideas for his life. After he graduated in 1793 with a degree in theology, he worked as a private tutor, among others for the son of Charlotte von Kalb, a close friend of Friedrich Schiller's. Through this connection, he was able to publish parts of his epistolary novel Hyperion in Schiller's periodical Die neue Thalia. At this time, Hölderlin also frequented the lectures of Johann Gottlieb Fichte at the University of Jena. Building on the ground-breaking realignment of philosophy by Immanuel Kant, Fichte, through his exploration of the self and human consciousness, became one of the founding fathers of German Idealism. The other two names usually associated with this movement, Friedrich Wilhelm Joseph Schelling and Georg Wilhelm Friedrich Hegel, had studied with Hölderlin in Tübingen, where they had become a tight-knit group of friends, united in their adoration of Greek antiquity and their fascination with the political upheavals in nearby France. While both Schelling and Hegel would eventually embark on successful academic careers, Hölderlin's ambition was to translate into poetry the ideas he and his fellow students at the Tübinger Stift had developed about culture, religion, and the self. At the center of Hölderlin's aspirations was the notion that the modern world had fragmented the human experience through the division of labor, the replacement of mythology through science, and the separation of state and church. $\mathrm{He}$ regarded literature as the singular means to regain the integrity of what it meant to be human. At the same time, he projected this idea of der ganze Mensch, the whole human, into an idealized past: ancient Greece, its religion, its philosophy, but most importantly, its poetry. Hölderlin thus saw it as Germany's, and not least his own, most honorable task to revive Greek culture in the present.

It doesn't seem far-fetched that such an endeavor would soon present insurmountable challenges to a young member of the middle class whose financial assets were withheld from him by a mother who did not approve of her son's deviation from the path that she had laid out for him. His chosen alternative, however, working as a private tutor, did not agree with a sensitive soul like Hölderlin's. Even though he had found an ardent supporter and admirer of his poetic talent in Charlotte von Kalb, he quit and left in 1795, possibly because he was frustrated over his lack of success in keeping von Kalb's son from masturbating.

From 1796 to 1798, Hölderlin was employed in Frankfurt am Main, tutoring the son of the banker Jakob Gontard. Soon, Hölderlin fell in love with Gontard' wife, Susette, and the feeling was mutual. The affair was eventually discovered and Hölderlin was dismissed from his position. This was followed by an unsteady period, in which the poet developed a range of short-lived plans, never quite settling for anything, but in which he also wrote some of the poems that 
would later become the cornerstones of his fame, like the elegy Brod und Wein. By the end of 1801, he was offered a position as a personal tutor in Bordeaux, and he set off on the journey on foot, arriving in Bordeaux in late January 1802. Even today, it remains unclear why Hölderlin decided to return to Germany as early as May of the same year. All we know is that he arrived in Stuttgart in June, in the most precarious state of mind. One of his friends describes Hölderlin as dressed like a beggar and pale as a corpse, with emaciated, hollow, and wild eyes, and long hair and beard (Safranski 244). The reason for the poet's departure from Bordeaux and his subsequent mental breakdown remain a mystery, and Safranski confines himself to presenting the reader with the different presumptions that scholars have come up with. It has been suspected that Hölderlin had been informed that his beloved Susette had fallen gravely ill. Indeed, she died of rubella on the 22nd of June that same year. From Hölderlin's letters, however, we know that he did not travel directly from Bordeaux to Germany, but took a detour via Paris, visiting an exhibition of ancient sculptures. It is thus very likely that his reasons for leaving his position were less dramatic, though a final answer remains to be found. The fact is, though, that Hölderlin never fully recovered from the mental breakdown that his friends and family witnessed after his return from France, even though he kept writing and even took up the position of librarian at the court of Homburg. There, he got entangled in a political intrigue surrounding his close friend and supporter Isaac Sinclair. Whether Hölderlin in fact participated in a plot to overthrow the Elector of Württemberg cannot be said with absolute certainty, also because soon after the accusations against Sinclair had been dropped, Hölderlin was taken to a psychiatric clinic, one of the first of its kind, in Tübingen. Released as incurable after a year and eight months, he was hosted by a local carpenter for the next thirty-six years until his death in 1843. While he continued to write, none of his poems achieved the quality and complexity of his previous work. He was able to interact with people, but signs of the shattered state of his mind were always obvious. While few of his friends and none of his family ever came to see him, he was frequently visited by admirers, and in 1826 a first collection of his poetry appeared, put together and edited by some of the most significant names in German Romanticism. At the age of 56 , Hölderlin had become a living, albeit silent, legend.

The achievement of Safranksi's biography is that he provides an accessible introduction to Hölderlin's life and the historical, as well as the aesthetic, context of his work. The cornerstones of the narrative are set by the poet's troubled relationship to his mother, the various friendships that connected him with the intellectual and literary networks of his time, and lastly the enigmatic elements of his life, particularly where they concern his various love affairs and the 
gradual deterioration of his mental state. As a profound expert in German thought, Safranski embeds Hölderlin's literary development within the contemporary philosophical discourse. Yet the author rarely manages to grasp the unique aesthetic quality of Hölderlin's writing. In comparison, for example, with Safranski's biographies of Schiller or Heidegger, this book feels like a work that has been commissioned by the publisher rather than originating in the author's genuine interest in the subject.

With Karl-Heinz Ott on the other hand, one can sense the personal investment the author has in his subject. As he strives to deconstruct the myth that has been created around Hölderlin, he intends to take on a significant section of continental academic thinking that values the apparent depth of thought over clarity of expression. Precisely because so much of Hölderlin's poetry cannot be reduced to the expression of ideas, he has been the point of reference for countless attempts to go beyond the limitations of Enlightenment rationality. Quite literally, this has been suggested by Pierre Bertaux, who introduced the idea that the poet's illness was merely a ploy to escape political persecution, while Michel Foucault looks at Hölderlin's madness more broadly and adduces the poet as an example of the kind of thinking that defies the modern adoration of reason. In short and critical fragments, Ott dismisses such fashionable exaltations. From the author's perspective, they have as little to do with the real Hölderlin as the poet's own projections of an idealized Greek antiquity. Ott does not, however, present us with his own reading of Hölderlin's life. At the end of Ott's long essay, we know little about Hölderlin himself, but much about the specters his name still summons in Germany and beyond. Even more, we learn about a well-read mind, its barely disguised frustrations with the German academic tradition, and its fascination with the obscure. Thus, following the first line of Hölderlin's poem Der Gang aufs Land that Safranski has chosen as the motto for his biography, Ott's book might inspire its readers to take a fresh look at the poet: Komm! ins Offene, Freund!Come! into the open, friend! The old paths have been cleared. A new one remains yet to be found.

Rüdiger Safranski, Komm! ins Offne, Freund! München: Hanser 2019. Karl-Heinz Ott, Hölderlins Geister. München: Hanser 2019. 